\title{
A DISAGGREGATED ANALYSIS OF THE IMPACT OF OUTPUT GAP ON INFLATION AND IMPLICATIONS FOR MONETARY POLICY
}

\section{Oguz Atuk, Mustafa Utku Özmen, Cagri Sarikaya*}

\begin{abstract}
This study investigates the sensitivity of Consumer Price Index (CPI) sub-items to output gap for an emerging market economy, Turkey. To this aim, we estimate standard Phillips Curve equations for each of the 152 sub-indices of the CPI and determine the goods and services that respond to output gap in a statistically and economically significant manner. Thereby, we propose an alternative view to assess core inflation as a complementary tool to better monitor underlying inflation with respect to its main drivers. Empirical findings show that about one-third of the consumer basket is affected by the output gap. Remaining items that are found to be insensitive to business cycle extensively co-move with import prices and exchange rate. The results imply that controlling inflation through counter-cyclical policies may be a more challenging issue, especially when external factors work in the opposite direction. Policy efforts to reduce exchange rate volatility and import content of aggregate production are as important as cyclical policies geared toward steering the economy with respect to its potential.
\end{abstract}

Keywords: business cycle, inflation, Phillips Curve, core inflation, Turkey

JEL Classification: E31, E32

\section{Introduction}

Sensitivity of inflation to output gap, namely the slope of the Phillips Curve (PC), has been a central issue in monetary policy debate. Knowledge of the sacrifice ratio (cost of disinflation) allows decision makers to design appropriate policy moves, thus to avoid excessive impact on the real economy. The question is more interesting for small-open economies, where monetary policy control over output and inflation may be a more challenging task. The presence of external factors such as world growth, global liquidity conditions, investors' risk appetite and prospects for large economies' policy paths may challenge monetary policy autonomy in emerging markets at times. The propagation of external developments over the domestic economy operates mainly through capital flows, particularly via exchange rate, and through import price channels. Hence, as the degree of globalization/openness rises the transmission of international shocks to smallopen economies may become stronger and may mitigate the effects of domestic policies.

* Oguz Atuk, Structural Economic Research Department, Central Bank of the Republic of Turkey, Ankara, Turkey (Oguz.Atuk@tcmb.gov.tr);

Mustafa Utku Özmen, Research and Monetary Policy Department, Central Bank of the Republic of Turkey, Ankara, Turkey (utkuozmen@gmail.com);

Cagri Sarikaya, Research and Monetary Policy Department, Central Bank of the Republic of Turkey, Ankara, Turkey (Cagri.Sarikaya@tcmb.gov.tr). 
Regarding inflation dynamics, the effect of globalization is discussed by a number of studies in the literature. Borio and Filardo (2007) emphasize the increasing role of " $g l o b e-$ centric" factors (global slack) rather than country-specific determinants (domestic slack) in explaining inflation. Zhang (2015) provides similar evidence for twenty-one emerging economies as a challenge for monetary policy conduct. The main policy implication of these findings for emerging market central banks is the possible need to respond to changes in global output gap. The necessity for designing appropriate policies aligned with external developments is also highlighted by Berument and Doan (2013) and Ülke and Berument (2015). They empirically show that not only the degree of openness but also the magnitude of capital flows has negative impact on monetary policy and interest rate effectiveness in Turkey.

Against this background, several studies raise the question of the potency of monetary policy in controlling inflation and investigate the relative importance of domestic and foreign determinants of inflation dynamics. Depending on the degree of integration with developed economies or on the degree of import orientation, Vašíček (2011) and Globan et al. (2016) point to the dominance of external factors rather than domestic real marginal cost in explaining inflation dynamics in selected Central and Eastern EU Member States. Similar conclusions are derived in various recent studies for Turkey, performed by Andiç et al. (2015) and Kara et al. (2017). ${ }^{1}$ The aforementioned studies point to the need for stabilizing the exchange rate and/or reducing the sensitivity of pricing mechanisms to such fluctuations as crucial elements for controlling inflation in these economies. ${ }^{2}$

Inflation-output gap relation has been investigated through the lense of aggregate CPI or aggregate core inflation measures in Turkey (i.e. Öğünç and Sarıkaya, 2011; Alp et al., 2012). However, on micro basis, CPI is composed of sub price indices with different pricing patterns (Özmen and Sevinç, 2016), which may exhibit different lags and degrees of sensitivity to business cycle. This heterogeneity may lead not only to mismeasurement of the elasticity (aggregation bias), but also to incomplete understanding of the transmission mechanism. Thus, in order to reveal goods and services through which the effect of the output gap is observed, a disaggregated approach is needed. Therefore, this study addresses the question of policy effectiveness by employing a disaggregated approach and we investigate the sensitivity of Consumer Price Index (CPI) sub-items to business cycle in Turkey. We follow a similar approach as Froehling and Lommatzsch (2011) and Hałka and Kotłowski (2014), albeit with a more detailed index classification. In this perspective, this study is the first of its kind in Turkey, and it is the first study considering this approach for a non-EU member emerging market economy to the best of our knowledge.

1 In a recent work, Kara et al. (2017) decompose consumer inflation in Turkey with respect to its main determinants for 2006-2016 period by estimating the contributions of exchange rate, import price, output gap, real unit wage and taxes to inflation. They empirically show that the exchange rate has been the major cost-push factor in driving consumer inflation, while the output gap is found to have a smaller role as a source of inflation in terms of both period averages and maximum impacts.

2 Lowering the exchange rate pass-through may call for economic policies to focus on a wide range of structural issues such as enhancing policy/institutional credibility, reducing import content of production, etc. 
We estimate PC equations for each of the 152 sub-groups of the COICOP 5-digit CPI and determine those prices of goods and services that respond to output gap in a statistically and economically significant manner. In this way, CPI is split into two parts: Cycledependent and cycle-independent. Such decomposition would contribute to better depiction of inflation dynamics, especially to monitoring the effects of business cycle fluctuations on prices, which are generally masked by external drivers of inflation in Turkey. In this way, we propose a complementary tool to conventional measures of core inflation for monitoring underlying inflation with respect to its main drivers.

Our results indicate that relatively smaller part of inflation can be associated with output gap in Turkey compared to European economies. Cycle-dependent part of the CPI is found to constitute one-third of the basket (in terms of weights), while inflation variations in the remaining part can be largely attributed to import price and exchange rate passthrough. Therefore, controlling domestic variables, i.e. aggregate demand or wages, may not be sufficient for a desired rate of disinflation or it may be too costly for the real economy. From another point of view, our findings also provide a basis for the consideration of economic policies in the pursuit of reducing exchange rate volatility and more importantly alleviating the sensitivity of domestic prices to exchange rate shocks.

\section{Data and Methodology}

The link between price indices and the output gap is established through the help of PCs. While generally the hybrid version including backward and forward looking components is used in macro models (i.e. Gali ve Gertler, 1999), in this empirical study we focus on the reduced-form PC. In doing so, we model each of the 152 sub-indices of the CPI (at COICOP 5-digit level) separately. Depending on the structure of the economy and on individual pricing dynamics, different PC specifications may suit better for different inflation series. Therefore, we consider three different PC specifications:

$$
\begin{gathered}
\pi_{t}=c+\alpha \pi_{t-1}+\beta \tilde{y}_{t-i}+\gamma \widetilde{\operatorname{rer}}+\varepsilon_{t}, \\
\pi_{t}=c+\alpha \pi_{t-1}+\beta \tilde{y}_{t-i}+\gamma \widetilde{r e r}+\gamma \widetilde{r u w_{t}}+\varepsilon_{t}, \\
\pi_{t}=c+\alpha \pi_{t-1}+\beta \tilde{y}_{t-i}+\gamma \widetilde{r e r_{t}}+\gamma \widetilde{r u w}+\delta \Delta \pi_{t-1}^{e x p}+\varepsilon_{t}, \\
\text { for } i=0, \ldots, 6,
\end{gathered}
$$

where $\pi$ is the quarterly inflation; $\tilde{y}$ is the output gap; $\widetilde{\text { rer }}$ is the real effective exchange rate (consumer price index based) gap; $\widetilde{r u w}$ is the real unit wage (non-farm hourly wage) gap; $\Delta \pi^{e x p}$ is the change in the medium term inflation expectations, and finally $\varepsilon$ is the error term.

Considering small-open economy dynamics, we introduce real exchange rate as an additional cost component to capture imported inflation. The variables regarding real marginal cost are defined as deviations from trend as prescribed by economic theory. The first specification amends the standard reduced-form PC with the real effective exchange rate. The second specification introduces real unit wage gap as well. If all the wages were cyclical in an economy, in principle, the output gap would be a good proxy for real unit 
labour costs. However, in Turkey, a significant portion of the wages is actually acyclical due to minimum wage setting behaviour (Aldan and Gürcihan Yüncüler, 2016), thus, we extend the initial specification with real unit wage gap. The standard PCs considered are backward looking in nature. However, inflation expectations also have an impact on current inflation dynamics. The appropriate way of incorporating expectations is to construct a structural model and estimate PCs within the model. However, such an endeavour is out of the scope of the current study. Yet as an approximation, we further include the lagged change in medium-term inflation expectations.

The main identification strategy builds on testing whether the output gap has a significant effect on inflation after controlling for other major determinants of inflation. In the above specification, where inflation of each sub-component is explained with its own lag, control variables and the output gap, a statistically significant and positive $\beta$ coefficient will point to the presence of the theoretically expected relationship between the output gap and inflation. If a sub price index satisfies this condition, the price index will be registered as cycle-dependent (and cycle-independent otherwise).

In the presence of heterogeneity among sub price indices, the estimated PC equations may differ in terms of lag structure and control variables. Given this model uncertainty, we estimate a wide range of models for each price index. First, we estimate each specification by alternating the lags of the output gap, ranging from 0 to 6 , to sufficiently account for the lags in transmission. Second, we alternate the control variables used. Overall, for 3 different specifications as outlined above, and for 7 different lags of the output gap, we estimate 21 different PC equations for each of the 152 sub price indices. In this framework, if we see that the coefficient of output gap is statistically significant and positive in at least two (out of three) of the above specifications, we consider that price index as output gap-sensitive, or cycle-dependent.

Our analysis is based on four key indicators: CPI inflation, output gap, real effective exchange rate gap and real unit wage gap. The quarterly data cover 2004Q1-2016Q3 period. Inflation is defined as quarterly percentage change in COICOP 5-digit CPI (2003=100) sub-indices provided by TurkStat. The price indices are used in seasonally adjusted form. Output gap, per cent deviation of GDP from its potential level, is the updated version of the estimates from Alp et al. (2012). ${ }^{3}$ Real effective exchange rate gap is defined as the deviation from HP-filtered trend of CPI-based real effective exchange rate provided by the Central Bank of Turkey (CBRT). Real unit wage gap is calculated as the deviation from HP-filtered trend of non-farm real hourly wage, produced by the authors based on the data from TurkStat. Medium-term inflation expectations are the 12-month-ahead inflation expectations reported in the CBRT Expectations Survey.

\section{Results}

In order to identify the cycle-dependent price indices, we run the above specifications for 152 sub price indices. The complete model results used for the selection of the cycle-dependent items are provided in the Appendix. Main findings can be summarized as follows:

3 For robustness purposes, we tried an alternative output gap measure calculated with the HP-filter. The results are found to be robust and our conclusions do not change. 
(i) One-third of the CPI (in terms of weight) is found to be sensitive to business cycle. We estimated statistically significant and positive coefficient for output gap in 46 items, constituting 32 per cent of the total CPI weights.

(ii) Procyclicality of inflation is more evident in services than in goods. Among the cycledependent items, 62 per cent of the services are found to be sensitive to output gap, whereas only 18 per cent of goods are procyclical. Transportation, restaurant/hotel, rent and maintenance services and mostly durable goods stand out as the major items that move parallel with the business cycle.

Against these findings, now we can proceed by introducing two new price indices by aggregating the relevant sub-items with respect to their weights in the CPI. Thereby we decompose headline inflation into two distinct components: Cycle-dependent and cycleindependent (Figure 1). Average annual inflation in cycle-dependent group (9.3 per cent) is higher than that of remaining items ( 7.4 per cent). The difference is more evident for pre-crisis episode due to sticky services inflation, which was characterized by a strong inertia, especially in rents. For the last two years of the sample, inflation in cycle-dependent prices were still higher on average, as output gap and/or real wages exerted greater pressure on inflation compared to imported costs.

Figure 1 | Aggregated Annual Inflation Series Based on Output Gap Sensitivity (\%)

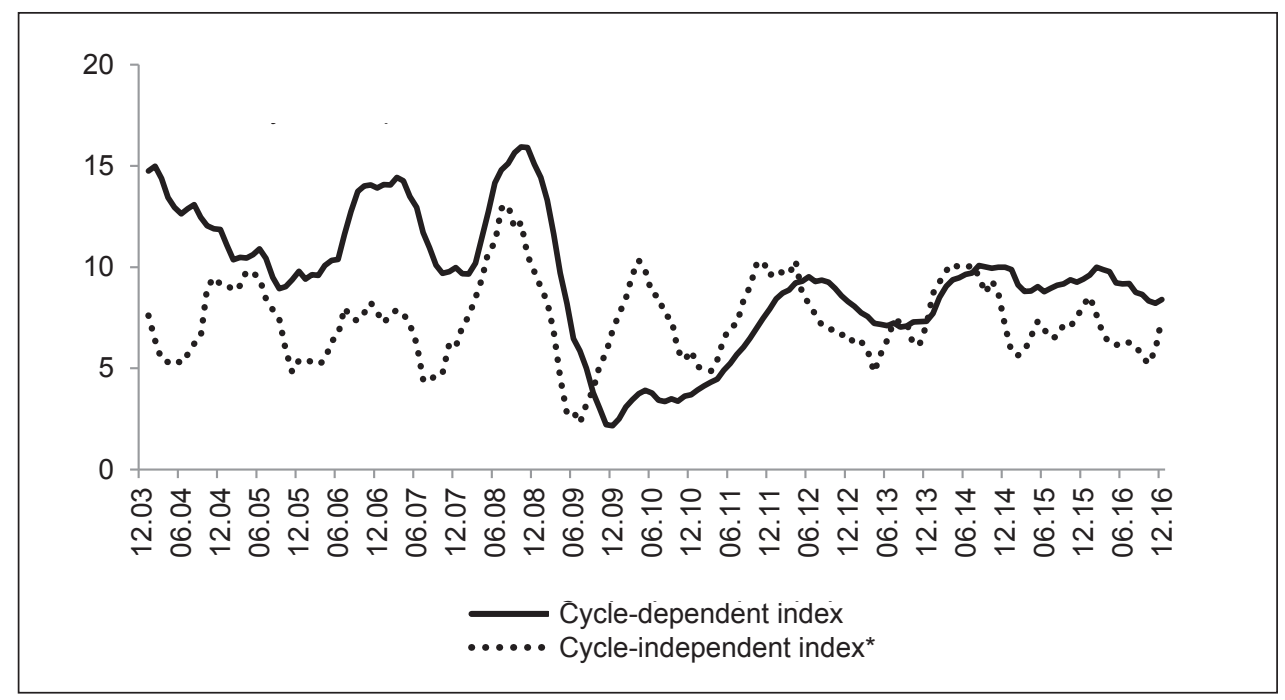

Notes: *Excludes fresh fruits-vegetables and alcohol-tobacco.

Source: Authors' calculations.

Inflation in cycle-dependent group also hovers in a wider range, between 2 and 16 per cent, while inflation in cycle-independent group fluctuates consistently in a narrower band, between 2 and 13 per cent. Moreover, cycle-independent group exhibit a more systematic 
pattern, probably reflecting the exchange rate fluctuations. The largest divergence between the cyclical behaviour of the two series is observed in the post-crisis episode, where cycledependent inflation picked up only gradually during the recovery phase.

(iii) Counter-cyclical policies may have only partial control over inflation. The weight of cycle-dependent items covers nearly one-third of the consumer basket. Therefore, successful control over cycle-dependent inflation may not warrant a desired level of inflation. From an emerging market point of view, global monetary policies and risk appetite steering capital flows may challenge the autonomy of domestic policies through the exchange rate channel. As an illustrative example, we can focus on the disinflation episode following the global crisis. During this period, inflation in cycle-dependent items even fell to as low as 2 per cent under subdued demand conditions, while the CPI inflation was around 6.5 per cent over the same period.

(iv) Large part of inflation variations can be attributed to import price and exchange rate pass-through. Inflation in cycle-independent group exhibits a strong relationship with domestic currency-denominated import prices (Figure 2). Considering again end-2009, inflationary role of these cost-push factors is clearly evident with 8.2 per cent inflation, despite the slump in aggregate demand and related group's inflation. Steady behaviour of this index, which accounts for more than half of the inflation basket, reveals that a significant part of inflation in Turkey could be explained by factors other than the domestic business cycle.

Figure 2 | Annual Inflation in Cycle-Independent Index and Import Price Index (\%)

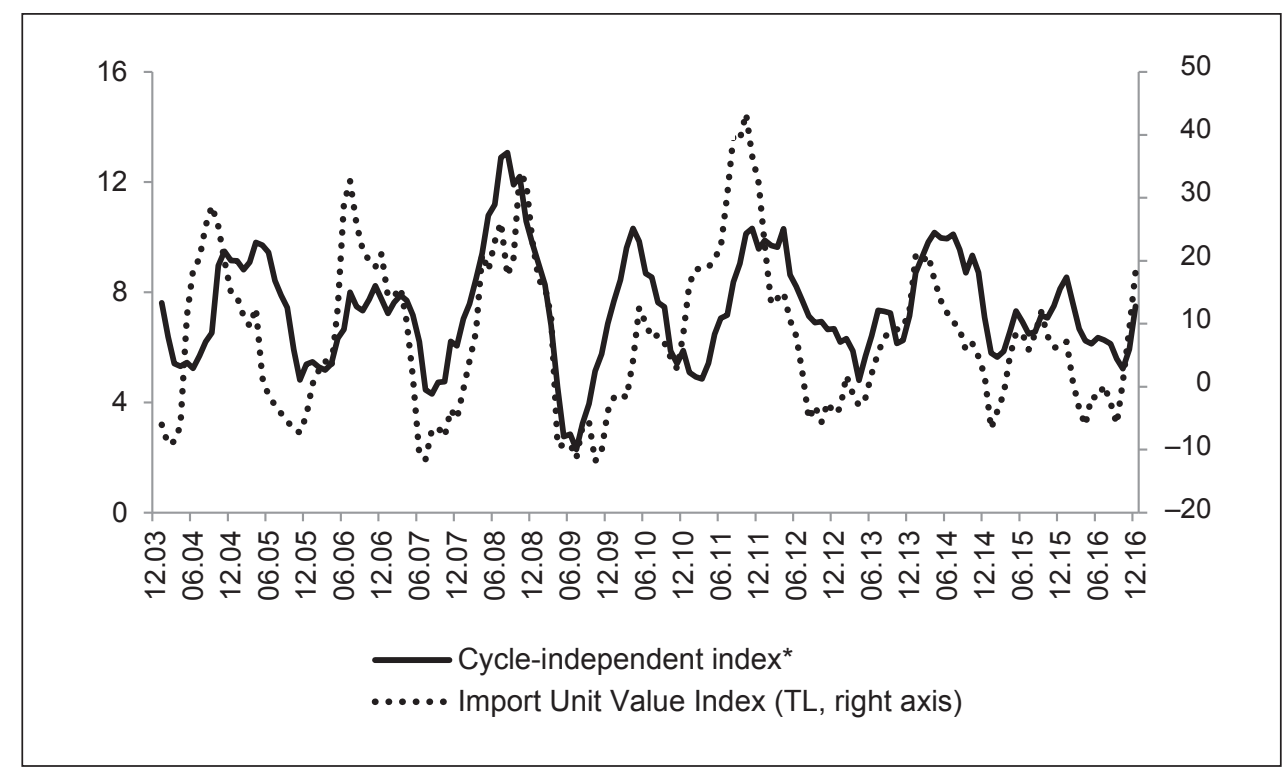

Notes: *Excludes fresh fruits-vegetables and alcohol-tobacco.

Source: TurkStat, Authors' calculations. 


\section{Implications for Monetary Policy}

\section{(i) An international comparison}

The weight of cycle-dependent items in the CPI is found to be 32 per cent. The first question that comes to mind is how large this weight is compared to other countries. There are similar studies focusing on European countries in the literature. Froehling and Lommatzsch (2011) found the average weight of the output-sensitive index to be 56 per cent for 16 Euro area countries studied. Similarly, Hałka and Kotłowski (2014) calculated this weight as around 55 per cent for Poland. Figure 3 illustrates a country-based comparison regarding the weight of output-sensitive items in respective inflation baskets.

Figure 3 | Output Gap Sensitivity of Inflation: An International Comparison (\%)

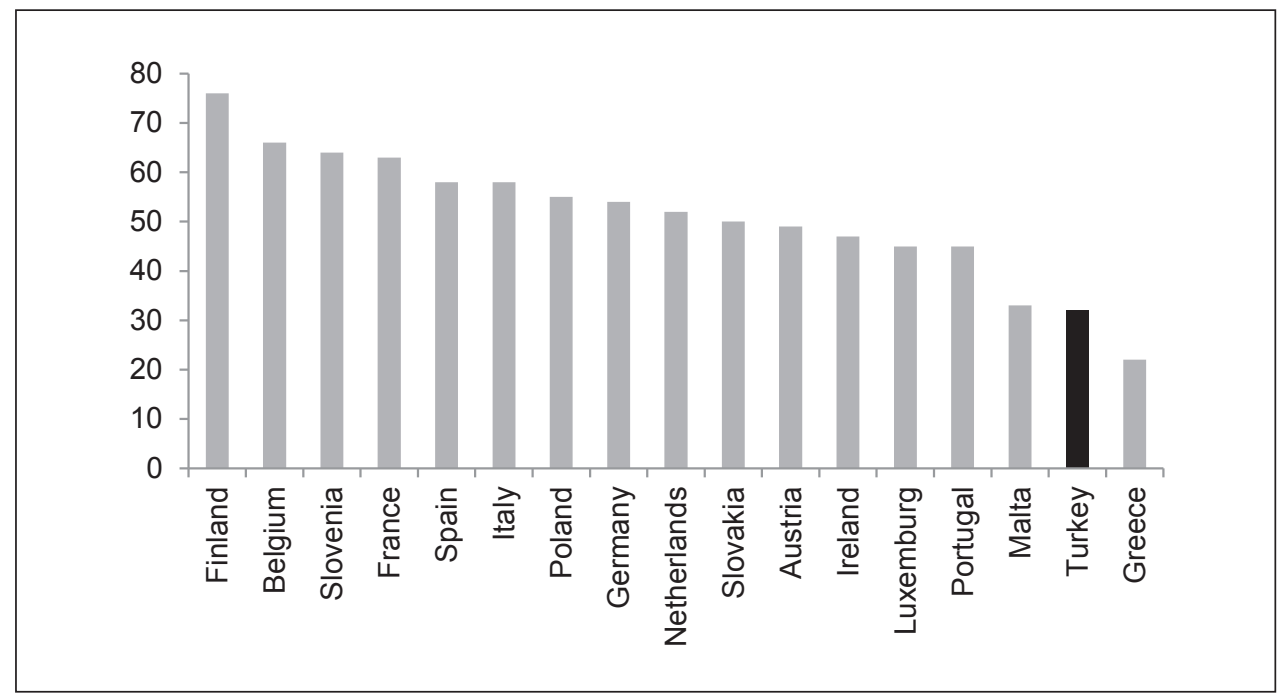

Source: The figure for Turkey is from Authors' calculations; the figure for Poland is from Halka and Kotlowski (2014); other figures are from Froehling and Lommatzsch (2011).

In most of the European countries the weight of the output-sensitive items in the CPI is more than 50 per cent. Thus, the related weight being significantly lower in Turkey may imply that controlling inflation through counter-cyclical policies may be more challenging compared to European countries. Equivalently, we can also infer that real cost of disinflation in Turkey may be higher given relative significance of domestic and external determinants of inflation. ${ }^{4}$

$4 \quad$ It is worth to note that a more precise comparison on 'cost of disinflation' should be based on the magnitude of the sacrifice ratio measured as the slope of the Phillips curve (output gap elasticity of inflation) rather than the weight of the cycle-dependent part of the basket. 
(ii) A useful tool for identifying movements in underlying inflation

Permanent exclusion-based core inflation measures designed to monitor the underlying trend of inflation are widely used in policy analysis. However, since they contain heterogeneous sub-items of CPI, main drivers of underlying inflation (domestic and imported cost pressures) may not always be identified by tracking the course of such indicators of core inflation. On the contrary, decomposing CPI into two components based on the cyclicality of sub-indices (cycle-dependent and cycle-independent) enables us to spot the drivers of underlying inflation. Focussing on the period after global crisis will complement this discussion (Figure 4).

Figure 4 | Comparison of Annual Inflation (\%)

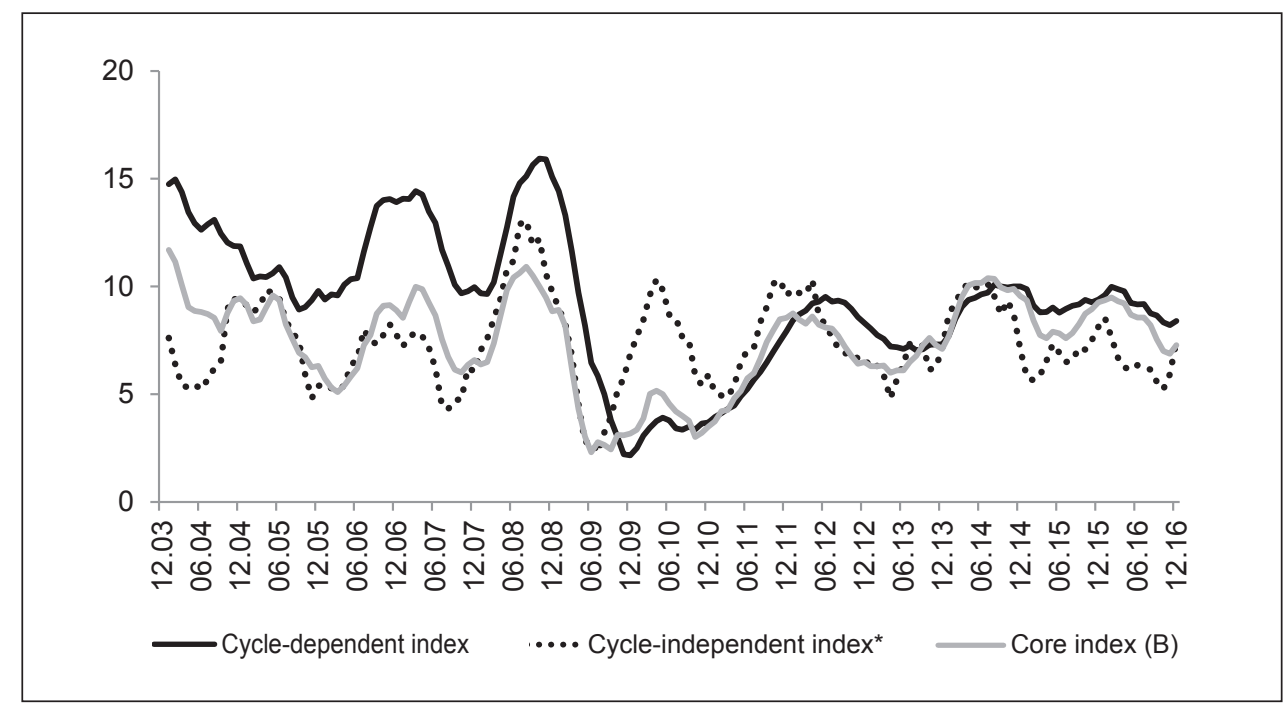

Notes: *Excludes fresh fruits-vegetables and alcohol-tobacco. Core index (B) is a widely followed core inflation measure in Turkey which excludes unprocessed food, energy, alcohol-tobacco and gold from the CPI.

Source: TurkStat, Authors' calculations.

Our findings show that core inflation in Turkey has a higher correlation with the cycledependent inflation. Here, we resort to a widely followed exclusion-based core inflation measure in Turkey, B (excludes unprocessed food, energy, alcohol-tobacco and gold from the CPI) for our discussion. The correlation coefficient between the B inflation and cycledependent (cycle-independent) inflation is $0.78(0.58)$ over the sample period. On the other hand this higher correlation does not hold for each point in the past, particularly for the year 2010. In this post-crisis episode, there were two opposing factors affecting inflation: (i) A deep and long-lasted slack in aggregate demand, (ii) a surge in Turkish lira-denominated import prices. In mid-2010, cycle-independent inflation breached 10 per cent, while core inflation stood at 5 per cent. Actually, the historically-low levels of core inflation during this period can completely be attributed to cycle-dependent groups, 
in which inflation was contained by subdued economic activity despite growing imported cost pressures (Figures 2 and 4). Thus, considering cycle-dependent and cycle-independent price indices together helps identify the underlying drivers of the movements in permanent exclusion-based core indicators.

(iii) An alternative approach for assessing core inflation: Cycle-dependency

Recognizing the main rationale behind the need for core inflation indicators, another advantage of the decomposition proposed in this article can be related to the idea of control over inflation. For instance, inflation in some food and energy items (i.e. flour, bread, water, solid fuel), which are generally excluded from the CPI in generating core inflation measures, are found to be sensitive to output gap. This finding suggests that permanent exclusion-based indicators, which remove aggregate groups from the CPI, may exclude valuable information that monetary policy should be concerned with. Therefore, the inclusion/exclusion decision should be motivated by considering each item rather than each aggregate group. From this perspective, a more selective inclusion strategy which keeps only the cycle-dependent items in the index may yield a more representative indicator of underlying inflation. Furthermore, a cyclicality-based indicator is dynamic in essence as it can be reconstructed over time due to changing economic structure, instead of relying on a static indicator of permanent exclusion method.

In a recent paper, Stock and Watson (2015) add food prices to core inflation measure on the grounds that they have become less volatile and more persistent recently in the US. Our study on the other hand, introduces not all, but a number of food items into core measures depending on their co-movement with economic cycle, which provides a more economic justification rather than statistical only.

For the case of Turkey, cycle-dependent price index offers another convenience. With only a limited portion of the price index, it may be possible to summarize the relevant information for the underlying trend. Nevertheless, the usual disclaimer for the use of core inflation indicators remains valid for cycle-dependent price index as well: one indicator cannot always satisfy all of the desired properties of core inflation measures. For instance, the items in the cycle-dependent price index are also influenced by imported inflation to some extent. Hence, the hike in cycle-dependent inflation over 2008 may partly be attributed to the impact of imported inflation. Yet, the consideration of cycle-dependency puts forward an economic criterion for the construction of a core inflation indicator which inherently contains the idea of control over inflation. Such an indicator facilitates better tracking of the control of monetary policy over inflation through the demand channel.

\section{Conclusion}

This paper investigates the sensitivity of CPI sub-items to business cycle in Turkey and decomposes inflation into two functional components: Cycle-dependent and cycleindependent. We find that only one-third of the CPI is sensitive to output gap and its remaining part mostly reflect imported inflation and exchange rate pass-through. An international comparison with European economies reveals that lower share of cycle-dependent items 
in the Turkish CPI may imply a greater challenge for counter-cyclical domestic policies targeting disinflation. We conclude that policy efforts aiming at reducing exchange rate volatility and limiting the sensitivity of domestic prices to external shocks emerge as central issues for achieving price stability. In that sense, building up more policy credibility and lowering the import content of aggregate production may be considered at the top of future policy agenda. All in all, this study not only contributes to better monitoring the effects of business cycle fluctuations on prices but also motivates further research on the structural component of inflation in Turkey.

\section{Appendix}

\section{Coefficient Estimates for Output Gap for Each Sub-group Inflation in Each Model Specification}

\begin{tabular}{|c|c|c|c|c|c|c|c|c|c|c|c|c|}
\hline & \multicolumn{4}{|c|}{ Specification 1} & \multicolumn{4}{|c|}{ Specification 2} & \multicolumn{4}{|c|}{ Specification 3} \\
\hline Items & $\begin{array}{l}\text { Coeffi- } \\
\text { cient }\end{array}$ & Std.e. & $t$-stat & $\begin{array}{l}\text { Lag } \\
\text { (best } \\
\text { fit) }\end{array}$ & $\begin{array}{l}\text { Coeffi- } \\
\text { cient }\end{array}$ & Std.e. & $t$-stat & $\begin{array}{l}\text { Lag } \\
\text { (best } \\
\text { fit) }\end{array}$ & $\begin{array}{l}\text { Coeffi- } \\
\text { cient }\end{array}$ & Std.e. & $t$-stat & $\begin{array}{c}\text { Lag } \\
\text { (best } \\
\text { fit) }\end{array}$ \\
\hline Rice & 0.35 & 0.19 & $1.81^{*}$ & 0 & 0.43 & 0.34 & 1.27 & 5 & 0.44 & 0.37 & 1.21 & 5 \\
\hline $\begin{array}{l}\text { Wheat and other } \\
\text { cereals }\end{array}$ & 0.20 & 0.09 & $2.34^{*}$ & 1 & 0.13 & 0.11 & 1.19 & 1 & 0.12 & 0.11 & 1.15 & 1 \\
\hline Bread & 0.26 & 0.05 & $4.83^{*}$ & 0 & 0.15 & 0.07 & $2.25^{*}$ & 2 & 0.16 & 0.07 & $2.38^{*}$ & 2 \\
\hline $\begin{array}{l}\text { Other bakery } \\
\text { products }\end{array}$ & 0.08 & 0.04 & $1.94^{*}$ & 1 & 0.09 & 0.06 & 1.66 & 3 & 0.09 & 0.05 & $1.77^{*}$ & 0 \\
\hline Pasta products & 0.48 & 0.12 & $4.11^{*}$ & 2 & 0.37 & 0.12 & $3.13^{*}$ & 2 & 0.30 & 0.10 & $3.18^{*}$ & 2 \\
\hline $\begin{array}{l}\text { Cereal preparations } \\
\text { and other cereal } \\
\text { products }\end{array}$ & 0.03 & 0.04 & 0.74 & 3 & 0.05 & 0.04 & 1.08 & 3 & 0.04 & 0.04 & 1.02 & 3 \\
\hline $\begin{array}{l}\text { Meat of bovine } \\
\text { animals }\end{array}$ & 0.20 & 0.14 & 1.43 & 6 & 0.20 & 0.14 & 1.43 & 6 & 0.22 & 0.15 & 1.50 & 6 \\
\hline $\begin{array}{l}\text { Meat of sheep and } \\
\text { goat }\end{array}$ & 0.13 & 0.20 & 0.64 & 6 & 0.13 & 0.20 & 0.65 & 6 & 0.16 & 0.21 & 0.74 & 6 \\
\hline Meat of poultry & 0.23 & 0.23 & 1.01 & 4 & 0.34 & 0.22 & 1.57 & 4 & 0.36 & 0.22 & 1.64 & 4 \\
\hline $\begin{array}{l}\text { Other meat and } \\
\text { edible offal }\end{array}$ & 0.13 & 0.21 & 0.64 & 6 & 0.13 & 0.20 & 0.66 & 6 & 0.15 & 0.21 & 0.73 & 6 \\
\hline $\begin{array}{l}\text { Processed meat and } \\
\text { other meat-based } \\
\text { preparations }\end{array}$ & 0.08 & 0.07 & 1.15 & 6 & 0.08 & 0.07 & 1.14 & 6 & 0.07 & 0.07 & 0.93 & 6 \\
\hline Fish and seafood & 0.03 & 0.12 & 0.22 & 6 & 0.10 & 0.15 & 0.67 & 2 & 0.09 & 0.14 & 0.62 & 2 \\
\hline $\begin{array}{l}\text { Raw milk; } \\
\text { pasteurized or } \\
\text { sterilized milk }\end{array}$ & 0.12 & 0.14 & 0.83 & 0 & 0.06 & 0.12 & 0.47 & 5 & 0.06 & 0.12 & 0.46 & 5 \\
\hline $\begin{array}{l}\text { Other milk-based } \\
\text { products }\end{array}$ & 0.10 & 0.09 & 1.19 & 1 & 0.07 & 0.10 & 0.63 & 1 & 0.08 & 0.12 & 0.65 & 1 \\
\hline Cheese and curd & 0.08 & 0.08 & 0.92 & 5 & 0.07 & 0.09 & 0.79 & 5 & 0.06 & 0.09 & 0.74 & 5 \\
\hline $\begin{array}{l}\text { Eggs and egg } \\
\text { products }\end{array}$ & 0.59 & 0.27 & $2.20^{*}$ & 0 & 0.54 & 0.39 & 1.38 & 2 & 0.27 & 0.37 & 0.71 & 2 \\
\hline $\begin{array}{l}\text { Butter and butter } \\
\text { products }\end{array}$ & 0.07 & 0.09 & 0.82 & 2 & 0.04 & 0.10 & 0.42 & 2 & 0.03 & 0.11 & 0.28 & 2 \\
\hline Margarine & 0.15 & 0.11 & 1.33 & 2 & 0.18 & 0.10 & $1.91^{*}$ & 2 & 0.24 & 0.16 & 1.50 & 0 \\
\hline Other oils and fats & 0.46 & 0.19 & $2.45^{*}$ & 1 & 0.26 & 0.20 & 1.25 & 1 & 0.28 & 0.21 & 1.30 & 1 \\
\hline $\begin{array}{l}\text { Fresh, chilled or } \\
\text { frozen fruit }\end{array}$ & 0.32 & 0.37 & 0.87 & 4 & 0.24 & 0.44 & 0.54 & 4 & 0.23 & 0.46 & 0.50 & 4 \\
\hline $\begin{array}{l}\text { Dried fruit, nuts and } \\
\text { edible seeds }\end{array}$ & 0.16 & 0.07 & $2.29 *$ & 1 & 0.07 & 0.11 & 0.64 & 1 & 0.05 & 0.10 & 0.50 & 1 \\
\hline $\begin{array}{l}\text { Fresh, chilled, } \\
\text { frozen or dried } \\
\text { vegetables }\end{array}$ & 0.12 & 0.43 & 0.27 & 5 & 0.17 & 0.53 & 0.32 & 3 & 0.26 & 0.51 & 0.51 & 3 \\
\hline
\end{tabular}


Coefficient Estimates for Output Gap for Each Sub-Group Inflation in Each Model Specification (continuation)

\begin{tabular}{|c|c|c|c|c|c|c|c|c|c|c|c|c|}
\hline \multirow[b]{2}{*}{ Items } & \multicolumn{4}{|c|}{ Specification 1} & \multicolumn{4}{|c|}{ Specification 2} & \multicolumn{4}{|c|}{ Specification 3} \\
\hline & $\begin{array}{l}\text { Coeffi- } \\
\text { cient }\end{array}$ & Std.e. & $t$-stat & $\begin{array}{l}\text { Lag } \\
\text { (best } \\
\text { fit) }\end{array}$ & $\begin{array}{l}\text { Coeffi- } \\
\text { cient }\end{array}$ & Std.e. & t-stat & $\begin{array}{l}\text { Lag } \\
\text { (best } \\
\text { fit) }\end{array}$ & $\begin{array}{l}\text { Coeffi- } \\
\text { cient }\end{array}$ & Std.e. & t-stat & $\begin{array}{c}\text { Lag } \\
\text { (best } \\
\text { fit) }\end{array}$ \\
\hline $\begin{array}{l}\text { Fresh or chilled } \\
\text { potatoes and other } \\
\text { tuber vegetables }\end{array}$ & 0.52 & 0.74 & 0.69 & 6 & 0.49 & 0.78 & 0.63 & 6 & 0.59 & 0.77 & 0.77 & 6 \\
\hline Legumes & 0.47 & 0.19 & $2.51^{*}$ & 0 & 0.32 & 0.22 & 1.48 & 2 & 0.33 & 0.24 & 1.37 & 2 \\
\hline $\begin{array}{l}\text { Preserved or } \\
\text { processed } \\
\text { vegetables }\end{array}$ & 0.01 & 0.05 & 0.18 & 1 & -0.02 & 0.09 & -0.16 & 1 & -0.04 & 0.14 & -0.26 & 0 \\
\hline Cane or beet sugar & 0.07 & 0.07 & 1.05 & 1 & 0.04 & 0.06 & 0.71 & 6 & 0.05 & 0.06 & 0.75 & 4 \\
\hline $\begin{array}{l}\text { Jams, marmalades } \\
\text { and honey }\end{array}$ & 0.21 & 0.07 & $2.94^{*}$ & 0 & 0.08 & 0.08 & 0.95 & 6 & 0.11 & 0.10 & 1.06 & 5 \\
\hline $\begin{array}{l}\text { Chocolates, sweets, } \\
\text { cocoa-based } \\
\text { preparations }\end{array}$ & 0.00 & 0.04 & -0.09 & 2 & 0.03 & 0.04 & 0.67 & 1 & 0.01 & 0.04 & 0.39 & 1 \\
\hline $\begin{array}{l}\text { Edible ice, ice cream } \\
\text { and sorbet }\end{array}$ & 0.08 & 0.14 & 0.58 & 3 & 0.13 & 0.15 & 0.87 & 3 & 0.14 & 0.15 & 0.95 & 3 \\
\hline Food products n.e.c. & 0.11 & 0.06 & $1.90^{*}$ & 0 & 0.04 & 0.06 & 0.69 & 1 & 0.05 & 0.07 & 0.82 & 0 \\
\hline Coffee & 0.03 & 0.06 & 0.45 & 3 & 0.02 & 0.08 & 0.26 & 3 & 0.02 & 0.08 & 0.23 & 3 \\
\hline Tea & 0.05 & 0.04 & 1.03 & 6 & 0.03 & 0.04 & 0.79 & 6 & 0.04 & 0.04 & 1.08 & 5 \\
\hline Cocoa & -0.05 & 0.06 & -0.79 & 2 & -0.02 & 0.07 & -0.26 & 2 & -0.02 & 0.07 & -0.32 & 2 \\
\hline $\begin{array}{l}\text { Water and mineral } \\
\text { waters }\end{array}$ & 0.11 & 0.03 & $4.20^{*}$ & 1 & 0.11 & 0.03 & $3.24^{*}$ & 2 & 0.09 & 0.03 & $3.40^{*}$ & 4 \\
\hline Soft drinks & 0.12 & 0.03 & $3.65^{*}$ & 2 & 0.14 & 0.04 & $3.44^{*}$ & 3 & 0.13 & 0.04 & $3.16^{*}$ & 3 \\
\hline $\begin{array}{l}\text { Fruit and vegetable } \\
\text { juices }\end{array}$ & 0.07 & 0.06 & 1.22 & 0 & 0.02 & 0.09 & 0.26 & 0 & 0.03 & 0.08 & 0.43 & 0 \\
\hline Spirits & -0.01 & 0.13 & -0.06 & 0 & 0.27 & 0.28 & 0.97 & 0 & 0.27 & 0.27 & 0.99 & 0 \\
\hline Wine & 0.09 & 0.08 & 1.07 & 0 & 0.43 & 0.20 & $2.17^{*}$ & 0 & 0.41 & 0.19 & $2.17^{*}$ & 0 \\
\hline Beer & -0.16 & 0.16 & -1.02 & 0 & 0.05 & 0.24 & 0.23 & 0 & 0.07 & 0.16 & 0.44 & 1 \\
\hline Cigarettes & 0.22 & 0.21 & 1.02 & 6 & 0.24 & 0.23 & 1.04 & 6 & 0.26 & 0.22 & 1.22 & 6 \\
\hline $\begin{array}{l}\text { Other tobacco } \\
\text { products }\end{array}$ & 0.06 & 0.19 & 0.30 & 2 & 0.70 & 0.80 & 0.87 & 0 & 0.69 & 0.80 & 0.86 & 0 \\
\hline Clothing materials & -0.03 & 0.04 & -0.70 & 1 & 0.01 & 0.07 & 0.14 & 1 & -0.03 & 0.06 & -0.61 & 1 \\
\hline Garments for men & -0.01 & 0.02 & -0.45 & 0 & -0.03 & 0.03 & -1.15 & 1 & -0.03 & 0.03 & -1.04 & 1 \\
\hline $\begin{array}{l}\text { Garments } \\
\text { for women }\end{array}$ & -0.01 & 0.03 & -0.17 & 1 & -0.01 & 0.05 & -0.30 & 1 & -0.01 & 0.05 & -0.21 & 1 \\
\hline $\begin{array}{l}\text { Garments } \\
\text { for children }\end{array}$ & -0.02 & 0.03 & -0.56 & 0 & -0.06 & 0.05 & -1.14 & 1 & -0.07 & 0.05 & -1.28 & 1 \\
\hline Garments for infants & 0.00 & 0.04 & -0.03 & 0 & -0.07 & 0.07 & -1.04 & 0 & -0.06 & 0.05 & -1.04 & 1 \\
\hline $\begin{array}{l}\text { Other articles } \\
\text { of clothing and } \\
\text { clothing accessories }\end{array}$ & 0.02 & 0.03 & 0.74 & 1 & -0.01 & 0.04 & -0.37 & 1 & -0.03 & 0.04 & -0.71 & 3 \\
\hline $\begin{array}{l}\text { Dry-cleaning, repair } \\
\text { and hire of clothing }\end{array}$ & 0.03 & 0.03 & 1.08 & 0 & 0.06 & 0.05 & 1.27 & 0 & 0.06 & 0.05 & 1.29 & 0 \\
\hline Footwear for men & 0.07 & 0.05 & 1.40 & 1 & 0.04 & 0.08 & 0.53 & 1 & 0.07 & 0.10 & 0.73 & 1 \\
\hline Footwear for women & 0.09 & 0.05 & $1.80^{*}$ & 1 & 0.06 & 0.05 & 1.09 & 1 & 0.07 & 0.06 & 1.14 & 1 \\
\hline $\begin{array}{l}\text { Footwear for } \\
\text { children and infants }\end{array}$ & 0.01 & 0.06 & 0.22 & 0 & -0.03 & 0.05 & -0.58 & 2 & -0.03 & 0.05 & -0.77 & 5 \\
\hline $\begin{array}{l}\text { Repair and hire } \\
\text { of footwear }\end{array}$ & 0.08 & 0.03 & $2.60^{*}$ & 1 & 0.14 & 0.03 & $4.06^{*}$ & 1 & 0.14 & 0.03 & $3.93^{*}$ & 1 \\
\hline
\end{tabular}




\section{Coefficient Estimates for Output Gap for Each Sub-Group Inflation in Each Model Specification (continuation)}

\begin{tabular}{|c|c|c|c|c|c|c|c|c|c|c|c|c|}
\hline & \multicolumn{4}{|c|}{ Specification 1} & \multicolumn{4}{|c|}{ Specification 2} & \multicolumn{4}{|c|}{ Specification 3} \\
\hline Items & $\begin{array}{l}\text { Coeffi- } \\
\text { cient }\end{array}$ & Std.e. & $t$-stat & $\begin{array}{l}\text { Lag } \\
\text { (best } \\
\text { fit) }\end{array}$ & $\begin{array}{l}\text { Coeffi- } \\
\text { cient }\end{array}$ & Std.e. & $t$-stat & $\begin{array}{l}\text { Lag } \\
\text { (best } \\
\text { fit) }\end{array}$ & $\begin{array}{l}\text { Coeffi- } \\
\text { cient }\end{array}$ & Std.e. & $t$-stat & $\begin{array}{c}\text { Lag } \\
\text { (best } \\
\text { fit) }\end{array}$ \\
\hline $\begin{array}{l}\text { Actual rentals for } \\
\text { housing }\end{array}$ & 0.02 & 0.01 & $2.98^{*}$ & 0 & 0.07 & 0.01 & $8.91^{*}$ & 0 & 0.08 & 0.01 & $8.76^{*}$ & 0 \\
\hline $\begin{array}{l}\text { Materials for the } \\
\text { maintenance and } \\
\text { repair of dwelling }\end{array}$ & 0.10 & 0.04 & $2.97^{*}$ & 2 & 0.11 & 0.05 & $2.08^{*}$ & 2 & 0.08 & 0.04 & $2.01^{*}$ & 1 \\
\hline Water supply & 0.15 & 0.09 & 1.65 & 6 & 0.15 & 0.09 & $1.72^{*}$ & 6 & 0.15 & 0.09 & 1.68 & 6 \\
\hline Refuse collection & -- & -- & -- & - & -- & -- & -- & -- & -- & -- & -- & - \\
\hline Electricity & 0.28 & 0.20 & 1.39 & 4 & 0.27 & 0.19 & 1.38 & 4 & 0.31 & 0.20 & 1.60 & 4 \\
\hline $\begin{array}{l}\text { Town gas and } \\
\text { natural gas }\end{array}$ & 0.39 & 0.23 & 1.65 & 2 & 0.42 & 0.24 & $1.76^{*}$ & 2 & 0.39 & 0.23 & 1.65 & 2 \\
\hline $\begin{array}{l}\text { Liquefied } \\
\text { hydrocarbons }\end{array}$ & 0.11 & 0.15 & 0.72 & 1 & 0.19 & 0.33 & 0.56 & 0 & 0.21 & 0.34 & 0.62 & 0 \\
\hline Liquid fuels & - & -- & - & - & -- & -- & -- & - & -- & -- & -- & - \\
\hline Solid fuels & 0.28 & 0.16 & $1.80^{*}$ & 3 & 0.34 & 0.21 & 1.64 & 2 & 0.22 & 0.13 & $1.71^{*}$ & 2 \\
\hline Kitchen furniture & 0.17 & 0.07 & $2.33^{*}$ & 1 & 0.19 & 0.09 & $2.09^{*}$ & 1 & 0.16 & 0.08 & $1.96^{*}$ & 1 \\
\hline Bedroom furniture & 0.11 & 0.21 & 0.51 & 1 & 0.49 & 0.29 & $1.68^{*}$ & 0 & 0.56 & 0.30 & $1.83^{*}$ & 0 \\
\hline $\begin{array}{l}\text { Living room } \\
\text { furniture }\end{array}$ & 0.24 & 0.21 & 1.14 & 1 & 0.29 & 0.23 & 1.28 & 0 & 0.38 & 0.23 & 1.67 & 0 \\
\hline $\begin{array}{l}\text { Carpets and other } \\
\text { floor coverings }\end{array}$ & -0.01 & 0.07 & -0.17 & 1 & -0.03 & 0.10 & -0.34 & 1 & -0.08 & 0.14 & -0.53 & 0 \\
\hline Household textiles & -0.04 & 0.05 & -0.69 & 1 & -0.01 & 0.07 & -0.15 & 1 & -0.07 & 0.06 & -1.17 & 1 \\
\hline $\begin{array}{l}\text { Refrigerators, } \\
\text { freezers and fridge- } \\
\text { freezers }\end{array}$ & 0.18 & 0.13 & 1.38 & 3 & 0.28 & 0.22 & 1.27 & 1 & 0.31 & 0.26 & 1.18 & 0 \\
\hline $\begin{array}{l}\text { Washing machines, } \\
\text { dryers, dishwashers }\end{array}$ & 0.22 & 0.12 & $1.89^{*}$ & 3 & 0.24 & 0.23 & 1.06 & 0 & 0.28 & 0.22 & 1.28 & 0 \\
\hline $\begin{array}{l}\text { Cookers, ovens and } \\
\text { microwave ovens }\end{array}$ & 0.14 & 0.11 & 1.24 & 3 & 0.05 & 0.12 & 0.39 & 6 & 0.04 & 0.13 & 0.28 & 6 \\
\hline $\begin{array}{l}\text { Air-conditioners, } \\
\text { humidifiers and } \\
\text { heaters }\end{array}$ & 0.15 & 0.04 & $3.57^{*}$ & 3 & 0.16 & 0.06 & $2.55^{*}$ & 1 & 0.13 & 0.06 & $2.32^{*}$ & 1 \\
\hline $\begin{array}{l}\text { Other major } \\
\text { household } \\
\text { appliances }\end{array}$ & 0.19 & 0.15 & 1.29 & 1 & 0.10 & 0.23 & 0.43 & 1 & 0.04 & 0.26 & 0.17 & 1 \\
\hline $\begin{array}{l}\text { Small electric } \\
\text { household } \\
\text { appliances }\end{array}$ & 0.27 & 0.09 & $3.08^{*}$ & 2 & 0.19 & 0.10 & $1.87^{*}$ & 2 & 0.27 & 0.18 & 1.51 & 0 \\
\hline $\begin{array}{l}\text { Repair of household } \\
\text { appliances }\end{array}$ & 0.06 & 0.09 & 0.69 & 0 & 0.17 & 0.10 & 1.67 & 2 & 0.27 & 0.14 & $1.94^{*}$ & 0 \\
\hline $\begin{array}{l}\text { Glassware and } \\
\text { ceramic ware for } \\
\text { indoor decoration }\end{array}$ & 0.05 & 0.02 & $2.07^{*}$ & 5 & 0.04 & 0.03 & $1.73^{*}$ & 5 & 0.05 & 0.03 & $1.70^{*}$ & 5 \\
\hline $\begin{array}{l}\text { Cutlery, flatware } \\
\text { and silverware }\end{array}$ & 0.05 & 0.04 & 1.18 & 0 & 0.04 & 0.03 & 1.17 & 2 & 0.05 & 0.07 & 0.80 & 0 \\
\hline $\begin{array}{l}\text { Non-electric } \\
\text { household articles } \\
\text { and kitchen utensils }\end{array}$ & 0.08 & 0.03 & $2.23^{*}$ & 0 & 0.08 & 0.05 & 1.67 & 2 & 0.06 & 0.04 & 1.64 & 1 \\
\hline $\begin{array}{l}\text { Small electric } \\
\text { accessories }\end{array}$ & 0.03 & 0.04 & 0.71 & 3 & 0.04 & 0.05 & 0.86 & 2 & 0.03 & 0.06 & 0.48 & 4 \\
\hline $\begin{array}{l}\text { Tools, garden } \\
\text { equipment and } \\
\text { other misc. } \\
\text { equipment }\end{array}$ & 0.16 & 0.07 & $2.27^{*}$ & 1 & 0.18 & 0.09 & $1.96^{*}$ & 1 & 0.13 & 0.08 & 1.68 & 1 \\
\hline
\end{tabular}


Coefficient Estimates for Output Gap for Each Sub-Group Inflation in Each Model Specification (continuation)

\begin{tabular}{|c|c|c|c|c|c|c|c|c|c|c|c|c|}
\hline & \multicolumn{4}{|c|}{ Specification 1} & \multicolumn{4}{|c|}{ Specification 2} & \multicolumn{4}{|c|}{ Specification 3} \\
\hline Items & $\begin{array}{l}\text { Coeffi- } \\
\text { cient }\end{array}$ & Std.e. & $t$-stat & $\begin{array}{c}\text { Lag } \\
\text { (best } \\
\text { fit) }\end{array}$ & $\begin{array}{l}\text { Coeffi- } \\
\text { cient }\end{array}$ & Std.e. & $t$-stat & $\begin{array}{l}\text { Lag } \\
\text { (best } \\
\text { fit) }\end{array}$ & $\begin{array}{l}\text { Coeffi- } \\
\text { cient }\end{array}$ & Std.e. & t-stat & $\begin{array}{l}\text { Lag } \\
\text { (best } \\
\text { fit) }\end{array}$ \\
\hline $\begin{array}{l}\text { Cleaning products } \\
\text { for household }\end{array}$ & 0.36 & 0.11 & $3.37^{*}$ & 1 & 0.37 & 0.16 & $2.31^{*}$ & 1 & 0.31 & 0.13 & $2.43^{*}$ & 1 \\
\hline $\begin{array}{l}\text { Other non-durable } \\
\text { household articles }\end{array}$ & 0.12 & 0.04 & $2.82^{*}$ & 3 & 0.10 & 0.05 & $2.14^{*}$ & 3 & 0.08 & 0.04 & $2.10^{*}$ & 3 \\
\hline Domestic services & 0.07 & 0.04 & $1.85^{*}$ & 1 & 0.07 & 0.03 & $2.36^{*}$ & 4 & 0.15 & 0.05 & $2.81^{*}$ & 1 \\
\hline $\begin{array}{l}\text { Laundering and } \\
\text { dry-cleaning of } \\
\text { household articles }\end{array}$ & 0.05 & 0.03 & 1.66 & 0 & 0.09 & 0.04 & $2.15^{*}$ & 1 & 0.11 & 0.05 & $2.40^{*}$ & 1 \\
\hline $\begin{array}{l}\text { Pharmaceutical } \\
\text { products }\end{array}$ & 0.10 & 0.07 & 1.43 & 3 & 0.13 & 0.08 & 1.62 & 3 & 0.12 & 0.08 & 1.58 & 3 \\
\hline $\begin{array}{l}\text { Other medical } \\
\text { products }\end{array}$ & 0.01 & 0.01 & 0.84 & 4 & 0.03 & 0.01 & $1.87^{*}$ & 4 & 0.03 & 0.02 & $1.82^{*}$ & 4 \\
\hline $\begin{array}{l}\text { Corrective } \\
\text { eyeglasses and } \\
\text { contact lenses }\end{array}$ & 0.23 & 0.16 & 1.51 & 2 & 0.38 & 0.19 & $1.96^{*}$ & 2 & 0.39 & 0.21 & $1.89^{*}$ & 2 \\
\hline $\begin{array}{l}\text { Other medical } \\
\text { products }\end{array}$ & 0.03 & 0.03 & 1.21 & 6 & 0.03 & 0.03 & 1.19 & 6 & 0.02 & 0.03 & 0.77 & 6 \\
\hline $\begin{array}{l}\text { Consultations } \\
\text { of physicians in } \\
\text { specialist practice }\end{array}$ & 0.02 & 0.03 & 0.91 & 0 & 0.14 & 0.06 & $2.22^{*}$ & 0 & 0.14 & 0.06 & $2.26^{*}$ & 0 \\
\hline Dental services & 0.13 & 0.08 & 1.65 & 1 & 0.16 & 0.10 & 1.61 & 1 & 0.16 & 0.11 & 1.54 & 1 \\
\hline $\begin{array}{l}\text { Services of medical } \\
\text { analysis lab., x-ray } \\
\text { centers }\end{array}$ & 0.09 & 0.05 & $1.82^{*}$ & 1 & 0.02 & 0.03 & 0.67 & 5 & 0.02 & 0.03 & 0.67 & 6 \\
\hline $\begin{array}{l}\text { Services of freelance } \\
\text { nurses and midwives }\end{array}$ & -- & -- & -- & -- & -- & -- & -- & -- & -- & -- & -- & -- \\
\hline Hospital services & 0.05 & 0.10 & 0.48 & 0 & 0.21 & 0.16 & 1.29 & 0 & 0.22 & 0.16 & 1.38 & 0 \\
\hline $\begin{array}{l}\text { Motor cars (diesel } \\
\text { engine) }\end{array}$ & 0.11 & 0.15 & 0.72 & 0 & 0.21 & 0.24 & 0.88 & 0 & 0.21 & 0.24 & 0.88 & 0 \\
\hline $\begin{array}{l}\text { Motor cars (gasoline } \\
\text { engine, } 1200-1699 \mathrm{cc} \text { ) }\end{array}$ & 0.15 & 0.14 & 1.02 & 0 & 0.24 & 0.20 & 1.16 & 0 & 0.28 & 0.20 & 1.39 & 0 \\
\hline Motor cars (2000 cc) & -- & -- & -- & -- & -- & -- & -- & -- & - & -- & -- & -- \\
\hline Motorcycle & 0.20 & 0.07 & $2.92^{*}$ & 0 & 0.24 & 0.13 & $1.76^{*}$ & 0 & 0.24 & 0.14 & $1.74^{*}$ & 0 \\
\hline Bicycle & 0.16 & 0.07 & $2.17^{*}$ & 4 & 0.12 & 0.07 & $1.73^{*}$ & 4 & 0.11 & 0.07 & 1.65 & 4 \\
\hline $\begin{array}{l}\text { Spare parts and } \\
\text { acc. for personal } \\
\text { transport } \\
\text { equipment }\end{array}$ & 0.15 & 0.05 & $2.91 *$ & 0 & 0.10 & 0.06 & $1.73^{*}$ & 2 & 0.13 & 0.07 & $1.83^{*}$ & 0 \\
\hline $\begin{array}{l}\text { Fuels and } \\
\text { lubricants for } \\
\text { personal transport } \\
\text { equipment }\end{array}$ & 0.08 & 0.19 & 0.43 & 0 & 0.07 & 0.37 & 0.19 & 0 & 0.11 & 0.22 & 0.49 & 1 \\
\hline $\begin{array}{l}\text { Maintenance and } \\
\text { repair of personal } \\
\text { transport eq. }\end{array}$ & 0.11 & 0.04 & $2.64^{*}$ & 1 & 0.15 & 0.05 & $3.12^{*}$ & 1 & 0.25 & 0.07 & $3.27^{*}$ & 0 \\
\hline $\begin{array}{l}\text { Other services in } \\
\text { respect of personal } \\
\text { transport eq. }\end{array}$ & 0.24 & 0.13 & $1.82^{*}$ & 0 & 0.26 & 0.54 & 0.48 & 0 & 0.26 & 0.56 & 0.46 & 0 \\
\hline $\begin{array}{l}\text { Intra-city passenger } \\
\text { transport by railway }\end{array}$ & 0.12 & 0.10 & 1.21 & 3 & 0.17 & 0.11 & 1.54 & 3 & 0.16 & 0.12 & 1.39 & 4 \\
\hline $\begin{array}{l}\text { Inter-city passenger } \\
\text { transport by railway }\end{array}$ & 0.15 & 0.10 & 1.56 & 1 & 0.27 & 0.15 & $1.74^{*}$ & 1 & 0.30 & 0.15 & $1.97^{*}$ & 1 \\
\hline
\end{tabular}




\section{Coefficient Estimates for Output Gap for Each Sub-Group Inflation in Each Model Specification (continuation)}

\begin{tabular}{|c|c|c|c|c|c|c|c|c|c|c|c|c|}
\hline \multirow[b]{2}{*}{ Items } & \multicolumn{4}{|c|}{ Specification 1} & \multicolumn{4}{|c|}{ Specification 2} & \multicolumn{4}{|c|}{ Specification 3} \\
\hline & $\begin{array}{l}\text { Coeffi- } \\
\text { cient }\end{array}$ & Std.e. & $t$-stat & $\begin{array}{c}\text { Lag } \\
\text { (best } \\
\text { fit) }\end{array}$ & $\begin{array}{l}\text { Coeffi- } \\
\text { cient }\end{array}$ & Std.e. & $t$-stat & $\begin{array}{c}\text { Lag } \\
\text { (best } \\
\text { fit) }\end{array}$ & $\begin{array}{l}\text { Coeffi- } \\
\text { cient }\end{array}$ & Std.e. & t-stat & $\begin{array}{c}\text { Lag } \\
\text { (best } \\
\text { fit) }\end{array}$ \\
\hline $\begin{array}{l}\text { Intra-city passenger } \\
\text { transport by bus }\end{array}$ & 0.09 & 0.04 & $1.91^{*}$ & 2 & 0.19 & 0.13 & 1.39 & 0 & 0.20 & 0.13 & 1.50 & 0 \\
\hline $\begin{array}{l}\text { Intra-city passenger } \\
\text { transport by taxi }\end{array}$ & 0.14 & 0.08 & $1.73^{*}$ & 0 & 0.15 & 0.14 & 1.06 & 0 & 0.15 & 0.14 & 1.04 & 0 \\
\hline $\begin{array}{l}\text { Inter-city passenger } \\
\text { transport by road }\end{array}$ & 0.15 & 0.05 & $2.91^{*}$ & 2 & 0.23 & 0.09 & $2.54^{*}$ & 1 & 0.21 & 0.10 & $2.23^{*}$ & 1 \\
\hline $\begin{array}{l}\text { Passenger transport by } \\
\text { sea and inland airway }\end{array}$ & 0.16 & 0.10 & 1.66 & 1 & 0.05 & 0.13 & 0.41 & 1 & 0.02 & 0.14 & 0.11 & 1 \\
\hline $\begin{array}{l}\text { Passenger transport by } \\
\text { sea and inland waterway }\end{array}$ & 0.23 & 0.11 & $2.05^{*}$ & 1 & 0.26 & 0.17 & 1.50 & 2 & 0.17 & 0.12 & 1.41 & 5 \\
\hline $\begin{array}{l}\text { Other purchased } \\
\text { transport services }\end{array}$ & 0.13 & 0.04 & $3.37^{*}$ & 0 & 0.13 & 0.06 & $2.41^{*}$ & 1 & 0.14 & 0.06 & $2.44^{*}$ & 1 \\
\hline Postal services & -0.03 & 0.25 & -0.12 & 6 & -0.02 & 0.26 & -0.08 & 6 & -0.06 & 0.26 & -0.23 & 6 \\
\hline $\begin{array}{l}\text { Telephone and telefax } \\
\text { equipment }\end{array}$ & -0.27 & 0.20 & -1.37 & 5 & 0.30 & 0.30 & 0.99 & 0 & 0.30 & 0.30 & 0.99 & 0 \\
\hline $\begin{array}{l}\text { Telephone and telefax } \\
\text { services }\end{array}$ & 0.10 & 0.06 & 1.57 & 6 & 0.10 & 0.06 & 1.56 & 6 & 0.10 & 0.07 & 1.53 & 6 \\
\hline $\begin{array}{l}\text { Television sets, video } \\
\text { cassette players and } \\
\text { recorders }\end{array}$ & 0.23 & 0.08 & $2.82^{*}$ & 5 & 0.20 & 0.09 & $2.16^{*}$ & 5 & 0.18 & 0.10 & $1.89^{*}$ & 5 \\
\hline $\begin{array}{l}\text { Radio sets, cd players, } \\
\text { other elec. acoustic } \\
\text { appliances }\end{array}$ & 0.06 & 0.07 & 0.84 & 1 & 0.18 & 0.22 & 0.80 & 1 & 0.21 & 0.26 & 0.82 & 1 \\
\hline $\begin{array}{l}\text { Photographic, } \\
\text { cinematographic eq. and } \\
\text { optical instr. }\end{array}$ & -0.06 & 0.17 & -0.38 & 2 & 0.18 & 0.14 & 1.29 & 2 & 0.09 & 0.16 & 0.58 & 2 \\
\hline $\begin{array}{l}\text { Information processing } \\
\text { equipment }\end{array}$ & 0.08 & 0.21 & 0.36 & 1 & 0.17 & 0.26 & 0.66 & 1 & 0.14 & 0.21 & 0.64 & 4 \\
\hline $\begin{array}{l}\text { Pre-recorded cassettes, } \\
\text { diskettes and cd-rom }\end{array}$ & 0.03 & 0.03 & 1.12 & 2 & 0.07 & 0.05 & 1.43 & 2 & 0.06 & 0.05 & 1.14 & 3 \\
\hline $\begin{array}{l}\text { Unrecorded cassettes, } \\
\text { diskettes and cd-rom }\end{array}$ & 0.05 & 0.04 & 1.09 & 0 & -0.07 & 0.05 & -1.26 & 3 & -0.08 & 0.06 & -1.43 & 3 \\
\hline $\begin{array}{l}\text { Repair of audio-visual, } \\
\text { photographic other } \\
\text { equipment }\end{array}$ & 0.06 & 0.09 & 0.72 & 4 & 0.16 & 0.10 & 1.63 & 1 & 0.16 & 0.10 & 1.54 & 1 \\
\hline $\begin{array}{l}\text { Musical instruments and } \\
\text { indoor recreation articles }\end{array}$ & 0.03 & 0.02 & 1.42 & 4 & 0.05 & 0.03 & $2.09^{*}$ & 2 & 0.04 & 0.03 & 1.53 & 4 \\
\hline Games, toys and hobbies & 0.13 & 0.06 & $2.06^{*}$ & 1 & 0.16 & 0.10 & $1.72^{*}$ & 1 & 0.10 & 0.06 & 1.59 & 1 \\
\hline $\begin{array}{l}\text { Equipment for sport, } \\
\text { camping and open-air } \\
\text { recreation }\end{array}$ & 0.02 & 0.05 & 0.35 & 0 & -0.05 & 0.06 & -0.87 & 2 & -0.06 & 0.06 & -1.02 & 2 \\
\hline $\begin{array}{l}\text { Veterinary and other } \\
\text { services for pets }\end{array}$ & 0.03 & 0.03 & 1.03 & 0 & 0.06 & 0.02 & $2.83^{*}$ & 3 & 0.05 & 0.02 & $2.80^{*}$ & 3 \\
\hline $\begin{array}{l}\text { Recreational and } \\
\text { sporting services }\end{array}$ & 0.13 & 0.17 & 0.79 & 6 & 0.14 & 0.17 & 0.82 & 6 & 0.16 & 0.18 & 0.90 & 6 \\
\hline Photography services & 0.05 & 0.03 & 1.54 & 0 & 0.06 & 0.04 & 1.45 & 1 & 0.04 & 0.04 & 1.16 & 1 \\
\hline Oher cultural services & 0.04 & 0.04 & 1.13 & 1 & 0.10 & 0.05 & $2.05^{*}$ & 1 & 0.08 & 0.04 & $1.81^{*}$ & 1 \\
\hline Games of chance & 0.11 & 0.21 & 0.52 & 0 & 0.62 & 0.73 & 0.84 & 0 & 0.22 & 0.23 & 0.94 & 1 \\
\hline Books & 0.42 & 0.27 & 1.57 & 6 & 0.47 & 0.27 & $1.76^{*}$ & 6 & 0.49 & 0.28 & $1.79^{*}$ & 6 \\
\hline $\begin{array}{l}\text { Newspapers and } \\
\text { periodicals }\end{array}$ & 0.30 & 0.11 & $2.66^{*}$ & 4 & 0.51 & 0.14 & $3.62^{*}$ & 4 & 0.51 & 0.13 & $3.86^{*}$ & 4 \\
\hline $\begin{array}{l}\text { Stationery and drawing } \\
\text { materials }\end{array}$ & 0.05 & 0.02 & $2.08^{*}$ & 4 & 0.05 & 0.03 & 1.31 & 3 & 0.03 & 0.03 & 1.07 & 4 \\
\hline Package holidays & 0.45 & 0.17 & $2.58^{*}$ & 0 & 0.23 & 0.27 & 0.83 & 0 & 0.24 & 0.28 & 0.88 & 0 \\
\hline $\begin{array}{l}\text { Pre-primary and primary } \\
\text { education }\end{array}$ & 0.02 & 0.05 & 0.38 & 6 & 0.11 & 0.04 & $3.08^{*}$ & 1 & 0.10 & 0.04 & $2.79^{*}$ & 1 \\
\hline
\end{tabular}




\section{Coefficient Estimates for Output Gap for Each Sub-Group Inflation in Each Model Specification (continuation)}

\begin{tabular}{|c|c|c|c|c|c|c|c|c|c|c|c|c|}
\hline \multirow[b]{2}{*}{ Items } & \multicolumn{4}{|c|}{ Specification 1} & \multicolumn{4}{|c|}{ Specification 2} & \multicolumn{4}{|c|}{ Specification 3} \\
\hline & $\begin{array}{l}\text { Coeffi- } \\
\text { cient }\end{array}$ & Std.e. & t-stat & $\begin{array}{l}\text { Lag } \\
\text { (best } \\
\text { fit) }\end{array}$ & $\begin{array}{l}\text { Coeffi- } \\
\text { cient }\end{array}$ & Std.e. & $t$-stat & $\begin{array}{l}\text { Lag } \\
\text { (best } \\
\text { fit) }\end{array}$ & $\begin{array}{l}\text { Coeffi- } \\
\text { cient }\end{array}$ & Std.e. & $t$-stat & $\begin{array}{l}\text { Lag } \\
\text { (best } \\
\text { fit) }\end{array}$ \\
\hline Secondary education & 0.04 & 0.08 & 0.47 & 1 & 0.17 & 0.06 & $3.06^{*}$ & 1 & 0.16 & 0.06 & $2.73^{*}$ & 1 \\
\hline $\begin{array}{l}\text { Post-secondary non- } \\
\text { tertiary education }\end{array}$ & -0.05 & 0.08 & -0.60 & 1 & 0.05 & 0.04 & 1.17 & 1 & 0.06 & 0.05 & 1.19 & 1 \\
\hline Tertiary education & 0.05 & 0.03 & 1.50 & 6 & 0.05 & 0.03 & 1.39 & 6 & 0.05 & 0.03 & 1.31 & 6 \\
\hline $\begin{array}{l}\text { Education not definable } \\
\text { by level }\end{array}$ & 0.05 & 0.05 & 1.11 & 1 & 0.09 & 0.06 & 1.51 & 1 & 0.11 & 0.07 & 1.53 & 1 \\
\hline $\begin{array}{l}\text { Catering services } \\
\text { (food products) }\end{array}$ & 0.05 & 0.03 & $1.80^{*}$ & 6 & 0.05 & 0.03 & $1.76^{*}$ & 6 & 0.05 & 0.03 & $1.74^{*}$ & 6 \\
\hline $\begin{array}{l}\text { Catering services } \\
\text { (beverages) }\end{array}$ & 0.07 & 0.03 & $2.57^{*}$ & 2 & 0.07 & 0.03 & $2.40^{*}$ & 2 & 0.07 & 0.03 & $2.04^{*}$ & 2 \\
\hline $\begin{array}{l}\text { Hotels, boarding houses } \\
\text { and others }\end{array}$ & 0.07 & 0.05 & 1.44 & 0 & 0.14 & 0.11 & 1.23 & 0 & 0.12 & 0.11 & 1.11 & 0 \\
\hline $\begin{array}{l}\text { Other accommodation } \\
\text { services }\end{array}$ & 0.07 & 0.05 & 1.27 & 4 & 0.29 & 0.12 & $2.34^{*}$ & 0 & 0.28 & 0.12 & $2.34^{*}$ & 0 \\
\hline $\begin{array}{l}\text { Services of barbers and } \\
\text { like for men }\end{array}$ & 0.03 & 0.02 & 1.51 & 0 & 0.10 & 0.04 & $2.37^{*}$ & 0 & 0.11 & 0.04 & $2.73^{*}$ & 0 \\
\hline $\begin{array}{l}\text { Services of hairdressing } \\
\text { salons and like for } \\
\text { women }\end{array}$ & 0.02 & 0.04 & 0.56 & 0 & 0.22 & 0.06 & $3.52^{*}$ & 0 & 0.23 & 0.06 & $3.55^{*}$ & 0 \\
\hline $\begin{array}{l}\text { Electric appliances for } \\
\text { personal care }\end{array}$ & 0.11 & 0.05 & $2.40^{*}$ & 3 & 0.13 & 0.08 & 1.60 & 2 & 0.16 & 0.11 & 1.46 & 0 \\
\hline $\begin{array}{l}\text { Other appliances, articles } \\
\text { and pro. for personal care }\end{array}$ & 0.06 & 0.04 & 1.37 & 2 & 0.05 & 0.05 & 0.86 & 1 & 0.03 & 0.05 & 0.52 & 3 \\
\hline $\begin{array}{l}\text { Jewelry, clocks and } \\
\text { watches }\end{array}$ & 0.13 & 0.31 & 0.41 & 4 & 0.33 & 0.62 & 0.53 & 0 & 0.27 & 0.63 & 0.42 & 0 \\
\hline $\begin{array}{l}\text { Travel goods and other } \\
\text { personal articles }\end{array}$ & 0.03 & 0.04 & 0.76 & 2 & 0.05 & 0.04 & 1.17 & 2 & 0.02 & 0.04 & 0.46 & 2 \\
\hline $\begin{array}{l}\text { Miscellaneous personal } \\
\text { articles n.e.c. }\end{array}$ & 0.01 & 0.07 & 0.13 & 6 & 0.03 & 0.05 & 0.51 & 2 & 0.04 & 0.06 & 0.62 & 2 \\
\hline Social protection & 0.05 & 0.02 & $2.28^{*}$ & 1 & 0.13 & 0.03 & $4.14^{*}$ & 2 & 0.17 & 0.04 & $3.88^{*}$ & 1 \\
\hline $\begin{array}{l}\text { Insurance connected with } \\
\text { the dwelling }\end{array}$ & 0.16 & 0.08 & $1.94^{*}$ & 1 & 0.30 & 0.10 & $2.96^{*}$ & 1 & 0.38 & 0.12 & $3.15^{*}$ & 1 \\
\hline $\begin{array}{l}\text { Insurance connected with } \\
\text { health }\end{array}$ & -0.04 & 0.12 & -0.35 & 0 & -0.15 & 0.22 & -0.70 & 4 & -0.14 & 0.22 & -0.66 & 4 \\
\hline $\begin{array}{l}\text { Insurance connected with } \\
\text { transport }\end{array}$ & 0.07 & 0.10 & 0.71 & 5 & 0.02 & 0.11 & 0.17 & 6 & 0.02 & 0.10 & 0.23 & 6 \\
\hline $\begin{array}{l}\text { Other financial services } \\
\text { n.e.c. }\end{array}$ & -0.05 & 0.11 & -0.41 & 3 & 0.13 & 0.12 & 1.06 & 3 & 0.13 & 0.13 & 1.04 & 3 \\
\hline Other services n.e.c. & 0.41 & 0.21 & $1.94^{*}$ & 6 & 0.44 & 0.22 & $1.99^{*}$ & 6 & 0.46 & 0.23 & $2.05^{*}$ & 6 \\
\hline
\end{tabular}

Notes: Table reports the estimated output gap coefficients along with their standard errors and t-statistics. The output gap coefficients are reported only for the lagged value which produces the best model fit. The model specifications are as described in Data and Methodology section.

$t$-statistics with * refer to statistically significant coefficients at least at $10 \%$ level.

Source: Estimation results of the model specifications outlined in Section 2 for each item. 


\section{References}

Aldan, A., Gürcihan Yüncüler, H. B. (2016). Real Wages and the Business Cycle in Turkey. CBT. Working Paper No. 16/25.

Alp, H., Öğünç, F., Sarıkaya, Ç. (2012). Monetary Policy and Output Gap: Mind the Composition. CBT. Research Notes in Economics No. 2012/07.

Andıç, B. S., Küçük, H., Öğünç, F. (2015). Inflation Dynamics in Turkey: In Pursuit of a Domestic Cost Measure. Emerging Markets Finance and Trade, 51(2), 418-431, https://doi.org/10.108 0/1540496X.2015.1019771

Berument, H., Doan, B. (2003). Openness and the Effectiveness of Monetary Policy: Empirical Evidence from Turkey. Applied Economics Letters, 10(4), 217-221, https://doi.org/10.1080/1350485022000015842

Borio, C. E. V., Filardo, A. J. (2007). Globalisation and Inflation: New Cross-Country Evidence on the Global Determinants of Domestic Inflation. BIS. Working Paper No. 227, https://doi.org/10.2139/ssrn.1013577

Froehling, A., Lommatzsch, K. (2011). Output Sensitivity of Inflation in the Euro Area: Indirect Evidence from Disaggregated Consumer Prices. Deutsche Bundesbank. Discussion Paper Series 1, Economic Studies No. 2011/25.

Gali, J., Gertler, M. (1999). Inflation Dynamics: A Structural Econometric Analysis. Journal of Monetary Economics, 44(2), 195-222, https://doi.org/10.1016/S0304-3932(99)00023-9

Globan, T., Arčabić, V., Sorić, P. (2016). Inflation in New EU Member States: A Domestically or Externally Driven Phenomenon? Emerging Markets Finance and Trade, 52(1), 154-168, https://doi.org/10.1080/1540496X.2014.998547

Hałka, A., Kotłowski, J. (2014). Does the Domestic Output Gap Matter for Inflation in a Small Open Economy? Eastern European Economics, 52(3), 89-107, https://doi.org/10.2753/ EEE0012-8775520305

Kara, A. H., Öğünç, F., Sarıkaya, Ç. (2017). Inflation Dynamics in Turkey: A Historical Accounting. CBT. Research Notes in Economics No. 2017/03.

Öğünç, F., Sarıkaya, Ç. (2011). Invisible but not Imperceptible: Output Gap in Turkey (in Turkish). Central Bank Review, 11(2), 15-28.

Özmen, M. U., Sevinç, O. (2016). Price Rigidity in Turkey: Evidence from Micro Data. Emerging Markets Finance and Trade, 52(4), 1029-1045, https://doi.org/10.1080/15404 96X.2015.1047304

Stock, J. H., Watson, M. W. (2015). Core Inflation and Trend Inflation. National Bureau of Economic Research. Working Paper No. 21282, https://doi.org/10.3386/w21282

Ülke, V., Berument, H. (2015). Effectiveness of Monetary Policy under Different Levels of Capital Flows for an Emerging Economy: Turkey. Applied Economics Letters, 22(6), 441-445, https://doi.org/10.1080/13504851.2014.948668

Vašíček, B. (2011). Inflation Dynamics and the New Keynesian Phillips Curve in Four Central European Countries. Emerging Markets Finance and Trade, 47(5), 71-100, https://doi.org/10.2753/REE1540-496X470504

Zhang, C. (2015). The Effect of Globalization on Inflation in New Emerging Markets. Emerging Markets Finance and Trade, 51(5), 1021-1033, https://doi.org/10.1080/1540496X.2015.1039 